\title{
The Study of the role of Government In the Development of Agricultural Industrialization*
}

\author{
Wenhua Kong \\ Ideological and Political Department, Baoding College, Baoding, Hebei, 071000, China ( kjiansuoz@163.com)
}

\begin{abstract}
In the process of the development of the agricultural industrialization, there is a degree of government functions misplaced problem in some areas, the key to correct the dislocation of the government functions is to position accurately to the industrialization of agriculture in the role of government and government functions. Specifically, should be done in two points: First, the Government should strive to create a fair and orderly, enabling market operators to obtain a social average profit margin of the main market environment, and attract the social resources to the industrialization of agriculture activities. Second, the government should no longer 'do', no longer take the main functions of the industrialization of agriculture, no longer control 'should not control' thing, At the same time, 'should be tubes' thing pipe up .
\end{abstract}

Index Terms - agricultural industrialization, the role of government, unction's dislocation

\section{Introduction}

In the process of development of agricultural industrialization, there is a degree of government functions 'misplaced' problem in some areas, Such as local government become a 'subject' of the industrialization of agriculture, to 'movement' way of promoting the industrialization of agriculture, as vigorously as the processing enterprises engaged in development zones, and some even began to 'call' farmers only planted a product, and so on. The result is: the role of government can't play to come out, but restrict the development of the industrialization of agriculture .The author thinks that, in order to give full play to the government in the development of the agricultural industrialization in play, we must promote the government for the industrialization of agriculture activities in the correct function.

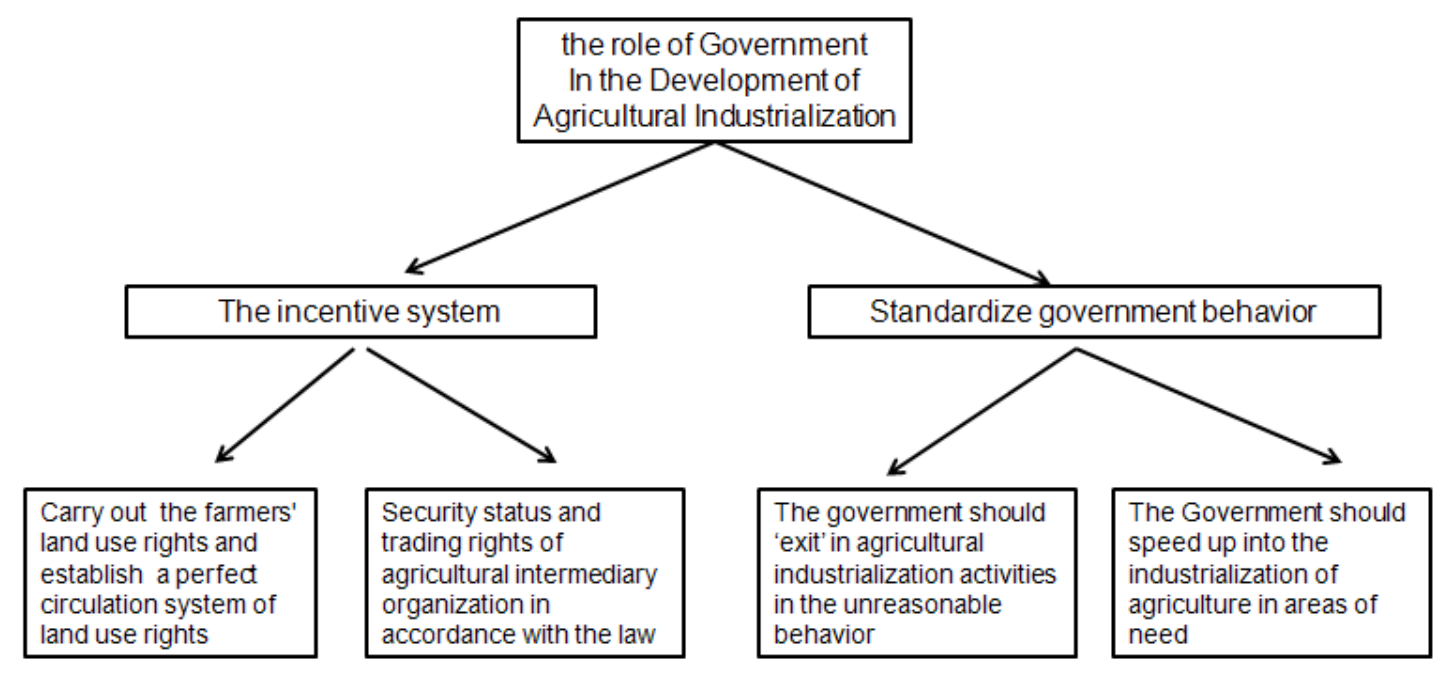

Fig. 1 the role of Government In the Development of Agricultural Industrialization

As shown in Figure 1, Correct the dislocation is the key government functions to the industrialization of agriculture in the role of government and government functions and accurate positioning. Agricultural industrialization is linking smallscale production of agricultural and the big social market as a market-oriented behavior, is the agricultural business and organizational forms which is compatible with the modern market economy. Therefore, the government roles and functions in the agriculture industrialization must meet the market economy principles and norms. Farmers and all kinds of agricultural intermediary organization is the industrialized operation of agriculture market main body, and the government departments is to conduct macro-regulation and the provision of public services in the main. Farmers and intermediary organizations to pursue their own interests to maximize is the power source of the development of agricultural industrialization, government support and promote the development of its auxiliary forces. Therefore, the

\footnotetext{
* The project was supported by the Scientific research team foundation of Baoding College.
} 
government's role is not primarily through their own participation, but through the main body of the industrialization of agriculture-farmers and the interests of various intermediary organizations, 'induced' to the health of agricultural industrialization and rapid development. Specifically, the government should do two things to correct the dislocation: First, the Government should strive to create a fair and orderly, enabling market operators to obtain a social average profit margin of the main market environment, and attract the social resources to the industrialization of agriculture activities. Second, the government should no longer 'do', took the main functions of the industrialization of agriculture, no longer control 'should not control' thing, At the same time, 'should be tubes' thing pipe up.

\section{Make the Income Expectations of the Main Body of Agricultural Industrialization Stable and Mobilize Their Agricultural Industrialization Activities}

Agricultural industrialization is the main profitmaximization as the main target, and only a clear legal status of market players, the real implementation of their responsibilities, powers and interests, so that each market players - the production operators and providers of factors of production can be compensated accordingly, to obtained considerable incentive, to mobilize their enthusiasm for contributing to the development of agricultural industrialization. For farmers, it is to implement long-term land use rights of farmers and the establishment of land use rights transfer system; for intermediary organizations, it is the law to protect the status of agricultural intermediaries and trading rights.

\section{A. Carry out the farmers' land use rights and establish a perfect circulation system of land use rights \\ Long-term use is an important measure which can} implement ownership interest and stable household income on the basis of not against the right of collective ownership of collective agriculture of the ultimate ownership interests. Long-term use rights is not clear that there are no significant social change in the case, farmers on the land he owned with the eternal or long-term possession and use rights. Last year, the central government brought forward the land contract 'thirty years' constant agricultural land contracted management policy, which is a big step compared with the original contract land short current situation, which to some extent, improve the farmers' production and investment initiative. However, 'thirty years' may be long, but after all, a time limit, the farmers do not trust. As the 'contract' is an interpretation of a variety of the concept is not very standardized, so even though the national policy in three decades has clearly defined the right to contract, including the right of return, use and transfer of rights during the period, but the incident that the rural grass-roots government at all levels break the contract often occurs. Therefore, only in law and protect farmers to clear land for a long time, can really use the party central committee on the 'carry out land contract' policy unchanged for long, can really mobilized farmers production and operation and the enthusiasm of the investment, and promote the development of the industrialization of agriculture.

Establish a sound land use rights transfer system. Some people worry that allowing the sale of land use rights will lead to polarization, leading to some of the sharp decline in living standards of farmers. Actually otherwise. Because, as the improvement of agricultural productivity, some farmers leave the land and some farmers need a lot of land is a historical trend, farmers trading land is a kind of objective need. It is, moreover, only to be able to achieve the right to use is 'complete' the right to use, so the government should establish and improve the agricultural land use rights transfer system as soon as possible. First, from a law explicitly agricultural land use right can be traded. The second is to establish a sound land use right price evaluation system, improve agricultural land use right price assessment training of personnel, regulate the land use right transfer rules and ensure that agricultural land use right transfer activities can be proceeded smoothly and in standardized manner.

B. Security status and trading rights of agricultural intermediary organization in accordance with the law

Agricultural intermediary organizations are economic organizations which link farmers with markets for farmers processing, sales and service .Under the current system, it is difficult for agricultural intermediaries to obtain sufficient incentive. First, since China does not have a law about agricultural industry of intermediary organizations, the legal status of agricultural intermediary organizations are not effectively protected. Government agencies at all levels have not speak up in agricultural intermediary organizations, the department also lack of corresponding foster intermediary organizations preferential policies. Second, the intermediary organization's own shortcomings, such as small-scale, low quality of personnel, its organizational structure is irrational and so on, limit their profitability, thus affecting their own development..Third, farmers and intermediary organizations, the relationship between the lack of coordination, between the two contracts lack of seriousness, a good market and sell when the poor farmers in breach of contract and sell bad when the intermediary organizations breach of contract, when the incident occurred, to the detriment of both sides of the transaction interests.

The key of protecting the intermediary organizations status and rights trading is to provide a good liberal institutional environment for the development of intermediary organizations. First, we must recognize the legal status of intermediaries. The form of legislation on agricultural properties of intermediary organizations, functions and organizational forms to be provided, to determine their legal status, legal status, protect their legitimate interests. The second is to improve the agricultural industry counterparts in support of intermediary organizations, institutions, such as government agencies have counterparts in support of their institutions, have their counterparts in support of preferential policies and preferential policies. In order to ensure the 
implementation of preferential policies can be used in the form of legislation. Third, in coordinating the relationship between farmers and intermediary organizations, the Government's role is mainly reflected in the specification and services: the formulation of relevant laws, such as agricultural joint-stock cooperative law and so on, regulate economic integration between them; agricultural policy regulations of the publicity, consulting, services, and help intermediary organizations and farmers build a scientific and standard joint; help farmers and intermediary organizations establish favourable for all parties the production and operation of risk guarantee system.

\section{Combine the 'Exit' with 'Enter', and Achieve the Rationalization of Government Action}

Here the so-called 'enter' and 'exit' means the government in the industrialization of agriculture activities in the entry and exit. That is, Regulate the behaviour of government agencies in the agricultural industrialization and eliminate the phenomenon of the tube did not mind, but should not pipe in the pipe.

\section{A. The government should 'exit' in agricultural industrialization activities in the unreasonable behavior}

To completely change the old system and led the formation of the Government to promote economic development situation. Don't give lower levels of government at all levels of government provides the progress of the development of agricultural industrialization and development indicators, and do not limit how much time to lower levels of government to engage in a 'pillar' industries, the number of 'leading' companies, not the development of agricultural industrialization progress bar into the performance of officials of the contents or index. Prevent the 'herd instinct', 'endless troubles'. As a government agency, they should put itself into perspective, separating the government and enterprise, themselves do not do the market main body, not directly intervene agricultural enterprise internal economic activity.

Gradually change the flow of administrative monopoly market situation of agriculture, the division of labour income to agricultural intermediary organizations. At this stage, the government's food system characterized by administrative monopoly plans to acquire the system of agricultural products, agricultural goods supply and marketing system is still the backbone of the agricultural distribution market, which makes it difficult to share agricultural intermediary organization to the division of labour income in the circulation. Despite the abolition of the national grain and cotton and other major acquisition and the procurement of agricultural products, but still holds a considerable part of agricultural plans to acquire rights. Acquisitions outside the few remaining products have, therefore, in the post-natal services, agricultural intermediaries is difficult to find the soil to survive. Because pesticides, fertilizer, plastic sheeting and agricultural seeds are produced by the government monopoly with seed companies, intermediary organizations in agricultural goods are also difficult to obtain living space. Solution to this problem is the government department in these areas exit properly, in ensuring the country's basic proprietary grain reserve system, and on the basis of circulation market, to let go of agricultural intermediary organizations to more living space.

\section{B. The Government should speed up into the industrialization of agriculture in areas of need \\ The Government's main responsibility is to provide} guidance, support, guidance, coordination, and services, information, infrastructure and other public services for the agricultural industrialization, and create a fair competitive environment to stimulate market demand for moderate growth. Specifically:

To do well in the industrialization of agriculture activities macro guidance. According to our country agricultural economy and national economic development of the specific conditions, National government should work out the specific circumstances of the country's macro-covering of the agricultural structure adjustment and development policy, governments at all levels in the country's macroeconomic policy under the guidance of the industrial structure, according to local agricultural economic development work out the actual situation of local needs for the agricultural industry promotion policy. Provide policy advice and guidance, policy and financial support for the agricultural industry Activities.

Provide better public services for the agricultural industry Activities. Agricultural industrialization is the specialized production, which is inseparable from social services support. However, the provision of social services can not rely on leading companies, primarily by the government. From the professional point of view, the leading business's main function is to deepen processing, market development, extending the agricultural industrial chain, the reason why the farmers now provide comprehensive services, is the result of social development lags behind, and therefore may not be, not rational behaviour. Distribution functions of the leading enterprises decide other services can only be a sideline, can not be the main industry, otherwise, their operations inevitably produce a pattern of large and affect the social services to the industry's direction. Therefore, the government should strive to establish and improve the social service system of the agricultural industry, establish and improve the agricultural production infrastructure and market system for the agricultural industry to create the conditions for rapid development.

Speed up the construction of agricultural social security system. The basic rule of market economy is survival of the fittest bullying, to maintain the stable operation of the socialist market economy, the social security system is essential. The industrialization of agriculture aims to achieve the modernization of the agricultural production, specialization and socialization and mercerization, achieve the link of agricultural small-scale production and social big markets is inseparable from the social security system. Therefore, to speed up the establishment agriculture social security system, mainly including: farmer's old-age security system, unemployment security system, medical security system, 
agriculture and preferential treatment policy of agricultural production, processing, management risk safe guard system.

Improve the quality of the farmers. In the process of development of agricultural industrialization, agricultural industrialization of the subject - the quality of farmers is an important contributing factor. From our present situation, the overall quality of farmers is relatively low, they do not understand the modern market economy, and they are not familiar to the market. The ability of participating in market competition is low, and the ability of profit is small. Therefore, we should put the agricultural technical training and improving the quality of the peasants in an important position. First, we must strengthen the farmers about the party's line, principles and policies, particularly in agriculture's line, principles and policies of education, so that the farmers of the results of their actions are 'aware'; the second is to improve education and rural education vocational and technical training; third is to improve agricultural.

\section{References}

[1] M. King, B. Zhu, and S. Tang, 'Optimal path planning,' Mobile Robots, vol. 8, no. 2, pp. 520-531, March 2001.

[2] H. Simpson, Dumb Robots, $3^{\text {rd }}$ ed., Springfield: UOS Press, 2004, pp.69.

[3] YE B, SU H, WEI L. Construction of Rural Sci-tech Information Service System in Guangxi Based on Demands of Agriculture Industrialization. Southwest China Journal of Agricultural Sciences, 2010, 2: 064.

[4] Barry P J. Industrialization of US agriculture: policy, research, and education needs. Agricultural and resource economics review, 2012, 24(1).

[5] NIU S, HAN X. Approach to Development Mode of Leisure Agriculture Industrialization in China. Journal of Shanxi Agricultural Sciences, 2010, 5: 025.

[6] Yan X. Study on Management Models and Countermeasures of Ecoagriculture Industrialization of Southwest Mountain. Journal of Anhui Agricultural Sciences, 2009, 1: 169.

[7] De Janvry A. Agriculture for development: New paradigm and options for success. Agricultural Economics, 2010, 41(s1): 17-36.

[8] Ying $\mathrm{H} \mathrm{Y}$. Anhui province green agriculture product all-in-one management's present situation, problem and countermeasure. Special Zone Economy, 2009, 6: 072.
[9] HUANG Z, Songhua M, CHEN L. Whole Industry Chain Management Mode and Mechanism Innovation of Agriculture Industrialization: Practice and Inspiration of 'Feixi Old Hens'. Agricultural Economics and Management, 2011, 6.

[10] Bei W. Empirical study on the relationship between China's industrialization, urbanization and agriculture modernization. Urban Problems, 2011, 9: 006.

[11] Zheng Z, Zhang C. Development of Agricultural Industrialization under the Background of Socialist New Countryside Construction. Journal of Anhui Agricultural Sciences, 2009, 35.

[12] Jian Z. Revelation from Taiwan Leisure Agriculture Development. Chinese Agricultural Science Bulletin, 2011, 11: 056.

[13] Vera-Cruz A O, Caballero R, Rocha A. Innovation intermediary organisations in the agriculture sector in Mexico. working paper, UAM, Mexico, 2011.

[14] DENG H, BI Q, DING Y, et al. A Study on the Operation Mechanism of Agriculture Technology Intermediary and its Optimization in Ethnic Districts-Based on the Empirical Research in Wutang Town, Xingning District, Nanning City. Science and Technology Management Research, 2011, 24: 017.

[15] DUAN Q, ZHANG R, CAO W. The Influences on Transfer of The Right to Land Contractual Management in Heibei Province. Animal Husbandry and Feed Science, 2009, 9: 086.

[16] YUAN F, YAN X. Trilateral Game Analysis on Collective Construction Land Transfer: in View of Local Governments, Rural Collectives and Land Using Enterprises. China Land Science, 2009, 2: 013.

[17] ZHOU R, CHEN M. Causes and Countermeasures of Low Efficiency of Current Rural Land Transfer-A Case Study of Hu'nan Province. Journal of Hebei Agricultural Sciences, 2010, 1: 032.

[18] Li Y. Thought on Rural Land Management Rights Transfer. Journal of University of Science and Technology Beijing (Social Sciences Edition), 2009, 1: 010.

[19] Wei N, Yong W, Yan S, et al. Government management and implementation of national real-time energy monitoring system for China large-scale public building. Energy Policy, 2009, 37(6): 20872091.

[20] Wang J. E-government security management: key factors and countermeasure //Proceedings of the 2009 Fifth International Conference on Information Assurance and Security-Volume 02. IEEE Computer Society, 2009: 483-486.

[21] Jackson M, Schell D, Taylor D R F. The evolution of geospatial technology calls for changes in geospatial research, education and government management. Directions Magazine (available online at http://www. directionsmag. com/article. php, 2009.

[22] Jacob C J, Lok C, Morley K, et al. Government management of two media-facilitated crises involving dioxin contamination of food. Public Understanding of Science, 2011, 20(2): 261-269. 